\title{
Full Characterization of Vatairea sp Wood Specie
}

\author{
Francisco A. Rocco Lahr ${ }^{1}$, Bruno H. C. Aftimus ${ }^{2}$, Felipe N. Arroyo ${ }^{3}$, Diego H. De Almeida ${ }^{4}$, \\ André L. Christoforo ${ }^{3, *}$, Eduardo Chahud ${ }^{5}$, Luiz A. M. Nunes Branco ${ }^{6}$ \\ ${ }^{1}$ Department of Structural Engineering (SET), São Paulo University (EESC/USP), São Carlos, Brazil \\ ${ }^{2}$ Department of Civil Engineering, University Center of Educational Foundation of Barretos (UNIFEB), Barretos, Brazil \\ ${ }^{3}$ Centre for Innovation and Technology in Composites - CITeC, Department of Civil Engineering (DECiv), Federal University of São \\ Carlos, São Carlos, Brazil \\ ${ }^{4}$ Department of Engineering, Pitágoras College, Poços de Caldas, Brazil \\ ${ }^{5}$ Department of Civil Engineering, Federal University of Minas Gerais (UFMG), Belo Horizonte, Brazil \\ ${ }^{6}$ Faculty of Engineering and Architecture, FUMEC University, Belo Horizonte, Brazil
}

\begin{abstract}
In Brazil, wood is a material which has been used for years in different purposes. The variety of Brazilian tropical wood species is expressive, nonetheless only a few of them are considered in structural design. Taking in account possibility of eventual shortages of these well-known wood species, characterization of alternative essences is presented as fundamental for maintenance of wood supply for civil construction. In Brazil, the structural dimensioning and timber characterization are specified by ABNT NBR 7190:1997 (Timber structures design), in its Annex B. This work aimed, with the aid of Brazilian Code, determining physical (4) and mechanical (13) properties of Angelim Saia (Vatairea sp.). Besides, with regression model (linear, exponential, geometric and logarithmic) based in analysis of variance (ANOVA), it was aimed to estimate resistance values and stiffness in function of the density, once this is an easy-obtainable property for wood. From a set of twelve aleatory pieces, twelve specimens were produced for each test type, totalizing 204 experimental measurements. Results of mechanical properties showed compatible performance with other species already established for use in structure, which shows the potential of Angelim Saia for structural purposes. From regression models for estimate strength and stiffness values, it was possible conclude that not all properties can be estimate by density. Better results were showed by the geometric model in estimation of hardness parallel to grain, who provided determination coefficient $\left(\mathrm{R}^{2}\right)$ close to $70 \%$.
\end{abstract}

Keywords Vatairea sp., Characterization, Density, Regression model

\section{Introduction}

Employing wood in construction is a practice carried out for many years by humanity, since the necessity of store food, overcoming obstacles, until the construction of shelters [1].

Initially, exploration of Amazon Tropical Forest was selective and predatory, once demand concentrated once only a few well-known wood species were extracted. This undesirable exploitation led those species (already completely characterized) to almost exhaustion, imposing to the market improve receptivity for new species not yet with a wide application [2].

Due to this high demand and few options, the prices of used species increase, give a new moment to Brazilian timber sector, being necessary define which new species can substitute the traditional used species in construction [3, 4]. In addition, with the growing awareness of population the use of materials which cause the minimum damage to the

* Corresponding author:

alchristoforo@gmail.com (André L. Christoforo)

Published online at http://journal.sapub.org/ijme

Copyright $(C 2016$ Scientific \& Academic Publishing. All Rights Reserved environment, timber originates from planted forests becomes also a building material to be widely considerable [5].

As such, Vatairea sp. is an interesting possibility, once this species occurs in several Brazilian regions, including Tocantins, Goiás and Bahia until São Paulo states. It is a very tall tree, with middle-heavy wood and potential satisfactory mechanical properties [6, 7].

However, before the using of a new species in any situation, be in roofs, bridges, silos or any others, it is necessary to determine its physical and mechanical properties, thus promoting a better condition to use [5].

Full characterization of wood species involves determination of their physical and mechanical properties, obeying requirements of normative Codes. In Brazil, is the NBR 7190 [8] who sets parameters for this characterization. However, the inconvenience of several of these tests and necessity of using heavy equipments, increase costs and make fundamental rely this work to research centers [8].

By other side, a physical property easily determined in usual experimental procedures is the apparent density (or simply density), set by ratio between mass and volume a $12 \%$ of moisture content (as referenced in Annex B, NBR 7190:1997). As density is a basic physical property, their 
values can, eventually, allow establish an adequate estimate of the mechanical wood properties $[9,10]$.

Therefore, the aim of this work is determinate the physical and mechanical properties of Vatairea sp. according to pre-defined indications of Brazilian Code, as well as research the possibility of estimating of mechanical properties in function of density.

\section{Material and Methods}

In order to reach proper conditions to get the specimens, Vatairea sp wood pieces were duly stored, until showing moisture content by $12 \%$, reference adopted by NBR 7190:1997 [8].

Mechanical tests were carried out in Wood and Timber Structures Laboratory (LaMEM), Department of Structural Engineering (SET), School of Engineering of São Carlos (EESC), University of São Paulo (USP). Physical tests were conducted in Federal University of Minas Gerais (UFMG) and FUMEC University laboratories. Statistical procedures were processed in Federal University of São Carlos (UFSCar).

Physical and mechanical properties were obtained under the requirements of test methods proposed by the Brazilian Code [8], in its Annex B (Determination of timber properties for structural purposes). The number of experimental determinations is introduced in Table 1, for each property, and it should be noted that, in total, 204 determinations were made.

To estimate mechanical properties by density, regression models (Expressions 1 to 4), reasoned on analysis of variance (ANOVA), have been tested in order to establish best fit between and each mechanical property investigated, in a way to establish mathematical reasons among them

$$
\begin{aligned}
Y & =a+b \cdot \rho_{12} & & {[\text { Lin - linear }] } \\
Y & =a \cdot e^{b \cdot \rho_{12}} & & {[\text { Exp - exponential }] } \\
Y & =a+b \cdot \operatorname{Ln}\left(\rho_{12}\right) & & {[\text { Log - logarithmic }] } \\
Y & =a \cdot \rho_{12}^{b} & & {[\text { Geo - geometric }] }
\end{aligned}
$$

ANOVA regression model was considered at confidence level $(\alpha) 5 \%$. Null hypothesis formulated consisted in the non-representativeness of the tested models $\left(\mathrm{H}_{0}: \beta=0\right)$ and as alternative hypothesis $\left(\mathrm{H}_{1}: \quad \beta \neq 0\right)$ was taken their representativeness. P-value upper than significance level adopted implies accepting $\mathrm{H}_{0}$ (model tested is not representative, i.e. variations in $\rho_{12}$ are unable to explain variations of the property), refuting it to otherwise (tested model is representative), being $\mathrm{Y}$ the dependent variable (value of properties studied).

Beyond use of ANOVA, that allows accepting or not the representativeness of models tested, the values of determination coefficient $\left(\mathrm{R}^{2}\right)$ were obtained as way to evaluate the capacity of variations $\rho_{12}$ to explain the variable analyzed. This enables, among the models considered significant, elect the one of better fit.

Table 1. Physical and mechanical properties of Vatairea $\mathrm{sp}$

\begin{tabular}{lcc}
\hline \multicolumn{1}{c}{ Properties } & Abbreviation & No Determinations \\
\hline $\begin{array}{l}\text { Density } \\
\text { Total radial shrinkage }\end{array}$ & $\rho_{12}$ & 12 \\
RRT & 12 \\
$\begin{array}{l}\text { Stral tangential shrinkage } \\
\text { parallel to the grain }\end{array}$ & $\mathrm{RTT}$ & 12 \\
$\begin{array}{l}\text { Strength in tension parallel to } \\
\text { the grain }\end{array}$ & $\mathrm{f}_{\mathrm{c} 0}$ & 12 \\
$\begin{array}{l}\text { Strength in tension normal to } \\
\text { the grain }\end{array}$ & $\mathrm{f}_{\mathrm{t} 00}$ & 12 \\
$\begin{array}{l}\text { Shear strength parallel to the } \\
\text { grain }\end{array}$ & $\mathrm{f}_{\mathrm{v} 0}$ & 12 \\
$\begin{array}{l}\text { Cracking } \\
\begin{array}{l}\text { Conventional strength in static } \\
\text { bending }\end{array}\end{array}$ & $\mathrm{f}_{\mathrm{s} 0}$ & 12 \\
$\begin{array}{l}\text { Longitudinal modulus of } \\
\text { elasticity in compression } \\
\text { parallel to the grain }\end{array}$ & $\mathrm{f}_{\mathrm{m}}$ & 12 \\
$\begin{array}{l}\text { Longitudinal modulus of } \\
\text { elasticity in tension parallel to } \\
\text { the grain }\end{array}$ & $\mathrm{E}_{\mathrm{c} 0}$ & 12 \\
$\begin{array}{l}\text { Conventional modulus of } \\
\text { elasticity in static bending }\end{array}$ & $\mathrm{E}_{\mathrm{t} 0}$ & 12 \\
$\begin{array}{l}\text { Hardness parallel to the grain } \\
\text { Hardness normal to the grain }\end{array}$ & $\mathrm{E}_{\mathrm{m}}$ & 12 \\
$\begin{array}{l}\text { Toughness } \\
\text { Strength in compression } \\
\text { normal to the grain }\end{array}$ & $\mathrm{f}_{\mathrm{H} 90}$ & 12 \\
$\begin{array}{l}\text { Modulus of elasticity in } \\
\text { compression normal to the } \\
\text { grain }\end{array}$ & $\mathrm{W}_{\mathrm{c} 90}$ & 12 \\
\hline & $\mathrm{E}_{\mathrm{c} 90}$ & 12 \\
& & \\
\hline
\end{tabular}

\section{Results and Discussion}

Tables 2 and 3 present means $(\bar{x})$, variation coefficients $(\mathrm{Cv})$, smallest (Min) and largest (Max) values for physical and mechanical properties, respectively.

The obtained mean value for fc0 $(64.2 \mathrm{MPa})$ is very close to that of Protium heptaphyllum (59 MPa) [11]. According to the authors, this permits utilization in all kinds of structures, for their high strength, far larger than obtained to the Paricá (Schizolobium amazonicum) - 24 MPa [9], Toona ciliate (27 $\mathrm{MPa}$ ) and Eucalyptus benthamii (37 MPa) [13], proper for light structures.

Table 2. Results obtained of physical properties of Vatairea $\mathrm{sp}$

\begin{tabular}{cccc}
\hline Stat. & $\begin{array}{c}\boldsymbol{\rho}_{\mathbf{1 2}} \\
\left(\mathbf{k g} / \mathbf{m}^{\mathbf{3}}\right)\end{array}$ & RRT (\%) & $\begin{array}{c}\text { RTT } \\
\mathbf{( \% )}\end{array}$ \\
\hline $\bar{x}$ & 760 & 4.24 & 8.20 \\
$C v$ & 0.08 & 0.19 & 0.11 \\
Mín & 0.68 & 3.19 & 6.15 \\
Máx & 0.88 & 5.50 & 8.90 \\
\hline
\end{tabular}


Table 3. Results obtained of mechanical properties of Vatairea $\mathrm{sp}$

\begin{tabular}{|c|c|c|c|c|c|c|}
\hline Stat. & $\mathrm{f}_{\mathrm{c} 0}(\mathrm{MPa})$ & $\mathrm{f}_{\mathrm{t} 0}(\mathrm{MPa})$ & $\mathrm{f}_{\mathrm{t90}}$ (MPa) & $\mathrm{f}_{\mathrm{v} 0}(\mathrm{MPa})$ & $\mathrm{f}_{\mathrm{s} 0}(\mathrm{MPa})$ & $\mathrm{f}_{\mathrm{m}}(\mathrm{MPa})$ \\
\hline $\bar{x}$ & 64.2 & 96 & 3.0 & 15 & 0.8 & 113 \\
\hline$C v$ & 0.14 & 0.22 & 0.21 & 0.12 & 0.16 & 0.20 \\
\hline Min & 46.7 & 33 & 1.9 & 12 & 0.6 & 76.6 \\
\hline Máx & 76.3 & 152 & 4.3 & 17 & 1.0 & 137 \\
\hline Stat. & $\mathrm{E}_{\mathrm{m}}(\mathbf{M P a})$ & $\mathbf{f}_{\mathrm{H} 0}(\mathrm{MPa})$ & $\mathrm{f}_{\mathrm{H} 90}(\mathrm{MPa})$ & W (J) & $\mathrm{f}_{\mathrm{c} 90}(\mathrm{MPa})$ & $\begin{array}{c}\mathbf{E}_{\mathrm{c} 90} \\
(\mathrm{MPa})\end{array}$ \\
\hline $\bar{x}$ & 18561 & 86.4 & 60.5 & 43 & 1.8 & 93.6 \\
\hline$C v$ & 0.11 & 0.11 & 0.15 & 0.13 & 0.13 & 0.12 \\
\hline Min & 14357 & 68 & 49 & 33 & 1.4 & 76.4 \\
\hline Máx & 22527 & 102 & 76 & 51 & 2.1 & 114.9 \\
\hline
\end{tabular}

According to Brazilian Code, from the obtained value for strength in compression parallel to the grain $\left(\mathrm{f}_{\mathrm{c} 0}\right)$, Vatairea $\mathrm{sp}$ be categorized as class $\mathrm{C} 40$ (dicotyledonous), presenting characteristic value $51 \mathrm{MPa}$ for that property.

The mean density $\left(0.760 \mathrm{~g} / \mathrm{cm}^{3}\right)$ classifies Vatairea $\mathrm{sp}$. as a heavy timber [14], same characteristic of Minquartia guianensis, Lecythis poiteaui, Mezilaurus itauba, Manilkara huberi e Brosimum rubescens [10]. However, it must be pointed out that density of these wood species varies between 0.835 to $0.904 \mathrm{~g} / \mathrm{cm}^{3}$, and they are widely applied in heavy structures.

Density of Vatairea sp. is higher comparing with Liquidambar sp. [15], Tectona grandis [9], Cedrela fissilis and Hovenia dulcis [16], whose densities range between 0.478 to $0.577 \mathrm{~g} / \mathrm{cm}^{3}$; and naturally more dense that Toona ciliata [12], Schizolobium amazonicum [5] e Gallesia integrifolia [16], which presented density varying between 0.318 to $0.370 \mathrm{~g} / \mathrm{cm}^{3}$ and, under certain conditions, can be employed in light structures.

Brazilian Code NBR 7190:1997 stipulates maximum values for variation coefficient, so that the characterization be qualified as compatible, being $18 \%$ for normal strengths and $28 \%$ for tangential efforts. All properties attended these parameters, except strength in tension parallel to the grain $\left(\mathrm{f}_{\mathrm{t} 0}\right)$ that exceeded the limit, presenting $\mathrm{Cv} 32 \%$. Despite this point, this characterization can be here considered as obeying the normative requirements.

Table 4 and 5 show ANOVA results of the regression models.

Table 4. Regression models obtained for strength properties of Vatairea $\mathrm{sp}$

\begin{tabular}{cccccc}
\hline & Models & P-value & a & b & $\boldsymbol{R}^{2}$ \\
\hline \multirow{4}{*}{$\mathbf{f}_{\mathbf{c} 0}$} & Lin & 0.0024 & -22.5178 & 0.1119 & $61.74 \%$ \\
& Exp & 0.0031 & 15.1567 & 0.0019 & $60.01 \%$ \\
& Log & 0.0019 & -512.1278 & 87.2739 & $63.57 \%$ \\
& Geo & 0.0023 & 0.0042 & 1.4483 & $62.15 \%$ \\
\hline & Models & P-value & a & b & $\boldsymbol{R}^{2}$ \\
\hline \multirow{4}{*}{$\mathbf{f}_{\mathbf{t} 0}$} & Lin & 0.5216 & 169.7591 & -0.0965 & $4.23 \%$ \\
& Exp & 0.6808 & 167.9310 & -0.0008 & $1.76 \%$ \\
& Log & 0.5156 & 595.2275 & -75.2330 & $4.35 \%$ \\
& Geo & 0.6653 & 6768.8975 & -0.6497 & $1.95 \%$ \\
\hline
\end{tabular}

\begin{tabular}{|c|c|c|c|c|c|}
\hline & Models & P-value & a & b & $R^{2}$ \\
\hline \multirow{5}{*}{$f_{\mathbf{t 9 0}}$} & Lin & 0.800 & 3.6277 & -0.0008 & $0.67 \%$ \\
\hline & Exp & 0.8284 & 3.5100 & -0.0002 & $0.49 \%$ \\
\hline & $\log$ & 0.7920 & 7.4599 & -0.6746 & $0.73 \%$ \\
\hline & Geo & 0.8203 & 10.5414 & -0.1934 & $0.54 \%$ \\
\hline & Models & P-value & $\mathbf{a}$ & b & $R^{2}$ \\
\hline \multirow{5}{*}{$f_{v 0}$} & Lin & 0.1788 & 4.7696 & 0.0128 & $17.29 \%$ \\
\hline & Exp & 0.1725 & 7.1856 & 0.0009 & $17.75 \%$ \\
\hline & $\log$ & 0.1742 & -51.5459 & 9.9656 & $17.62 \%$ \\
\hline & Geo & 0.1680 & 0.1299 & 0.7102 & $18.09 \%$ \\
\hline & Models & P-value & $\mathbf{a}$ & b & $R^{2}$ \\
\hline \multirow{5}{*}{$\mathbf{f}_{\mathbf{5} 0}$} & Lin & 0.0432 & -0.1546 & 0.0013 & $34.85 \%$ \\
\hline & Exp & 0.0388 & 0.2352 & 0.0017 & $36.09 \%$ \\
\hline & $\log$ & 0.0403 & -5.8843 & 1.0136 & $35.66 \%$ \\
\hline & Geo & 0.0360 & 0.0002 & 1.2841 & $36.94 \%$ \\
\hline & Models & P-value & $\mathbf{a}$ & b & $R^{2}$ \\
\hline \multirow{5}{*}{$\mathbf{f}_{\mathrm{m}}$} & Lin & 0.5497 & 161.0765 & -0.0673 & $3.69 \%$ \\
\hline & Exp & 0.5657 & 172.3715 & -0.0006 & $3.41 \%$ \\
\hline & $\log$ & 0.5803 & 427.3822 & -47.8819 & $3.16 \%$ \\
\hline & Geo & 0.5942 & 2001.7127 & -0.4406 & $2.94 \%$ \\
\hline & Models & P-value & $\mathbf{a}$ & b & $R^{2}$ \\
\hline \multirow{5}{*}{$\mathbf{f}_{\mathrm{H} 0}$} & Lin & 0.0009 & -8.7266 & 0.1218 & $68.20 \%$ \\
\hline & Exp & 0.0009 & 27.4957 & 0.0015 & $68.54 \%$ \\
\hline & $\log$ & 0.0008 & -541.2850 & 94.2800 & $69.20 \%$ \\
\hline & Geo & 0.0007 & 0.0460 & 1.1315 & $69.74 \%$ \\
\hline & Models & P-value & $\mathbf{a}$ & b & $R^{2}$ \\
\hline \multirow{5}{*}{$\mathbf{f}_{\mathrm{H} 90}$} & Lin & 0.0014 & -27.1222 & 0.1168 & $65.38 \%$ \\
\hline & Exp & 0.0014 & 14.2239 & 0.0019 & $65.81 \%$ \\
\hline & $\log$ & 0.0011 & -542.3691 & 91.1028 & $67.28 \%$ \\
\hline & Geo & 0.0010 & 0.0030 & 1.4954 & $67.77 \%$ \\
\hline & Models & P-value & $\mathbf{a}$ & b & $R^{2}$ \\
\hline \multirow{5}{*}{ W } & Lin & 0.6467 & 34.3649 & 14.5716 & $2.18 \%$ \\
\hline & Exp & 0.6584 & 35.1095 & 0.3274 & $2.03 \%$ \\
\hline & $\log$ & 0.6212 & 48.7810 & 12.0624 & $2.53 \%$ \\
\hline & Geo & 0.6345 & 48.5297 & 0.2703 & $2.35 \%$ \\
\hline & Models & P-value & $\mathbf{a}$ & b & $R^{2}$ \\
\hline \multirow{4}{*}{$\mathbf{f}_{\mathrm{c} 90}$} & Lin & 0.1817 & 0.7530 & 0.0013 & $17.08 \%$ \\
\hline & Exp & 0.1825 & 0.9714 & 0.0008 & $17.02 \%$ \\
\hline & $\log$ & 0.1655 & -5.3329 & 1.0724 & $18.29 \%$ \\
\hline & Geo & 0.1658 & 0.0278 & 0.6262 & $18.26 \%$ \\
\hline
\end{tabular}


Table 5. Regression models obtained for stiffness properties of Vatairea $\mathrm{sp}$

\begin{tabular}{|c|c|c|c|c|c|}
\hline & Models & P-value & $\mathbf{a}$ & b & $R^{2}$ \\
\hline \multirow{5}{*}{$\mathbf{E}_{\mathrm{c} 90}$} & Lin & 0.1572 & 1055.7369 & -1.1937 & $18.95 \%$ \\
\hline & Exp & 0.1399 & 2838.0686 & -0.0042 & $20.45 \%$ \\
\hline & $\log$ & 0.1410 & 6452.3906 & -950.7389 & $20.35 \%$ \\
\hline & Geo & 0.1255 & $6452.25 \mathrm{E}+8$ & -3.3742 & $21.84 \%$ \\
\hline & Models & P-value & $\mathbf{a}$ & b & $R^{2}$ \\
\hline \multirow{5}{*}{$\mathbf{E}_{\mathrm{c} 0}$} & Lin & 0.0095 & -8594.3112 & 37.0888 & $50.58 \%$ \\
\hline & Exp & 0.0095 & 4228.4203 & 0.0020 & $50.60 \%$ \\
\hline & $\log$ & 0.0074 & -173640.0982 & 29143.3296 & $52.87 \%$ \\
\hline & Geo & 0.0072 & 0.5677 & 1.5738 & $53.08 \%$ \\
\hline & Models & P-value & a & b & $R^{2}$ \\
\hline \multirow{5}{*}{$\mathbf{E}_{\mathbf{t} 0}$} & Lin & 0.1593 & 6137.6575 & 18.4202 & $18.78 \%$ \\
\hline & Exp & 0.1496 & 9830.1373 & 0.0009 & $19.58 \%$ \\
\hline & $\log$ & 0.1512 & -75390.5941 & 14407.4663 & $19.45 \%$ \\
\hline & Geo & 0.1415 & 157.8448 & 0.7301 & $20.30 \%$ \\
\hline & Models & P-value & a & b & $R^{2}$ \\
\hline \multirow{4}{*}{$\mathbf{E}_{\mathrm{m}}$} & Lin & 0.0353 & 3625.5189 & 19.5447 & $37.15 \%$ \\
\hline & Exp & 0.0352 & 8094.3915 & 0.0011 & $37.20 \%$ \\
\hline & $\log$ & 0.0315 & -82802.3614 & 15275.3311 & $38.42 \%$ \\
\hline & Geo & 0.0310 & 67.9929 & 0.8445 & $38.59 \%$ \\
\hline
\end{tabular}

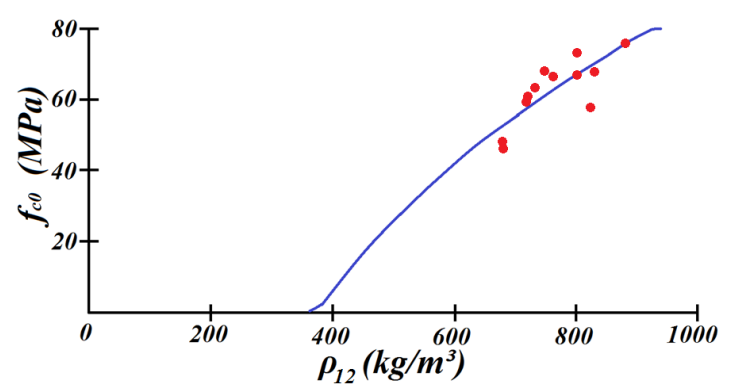

(a)

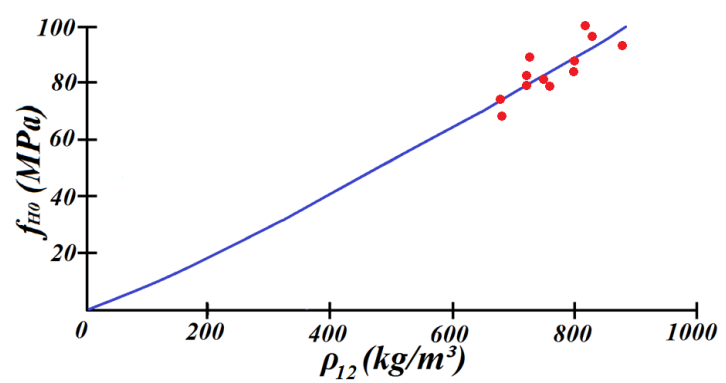

(b)

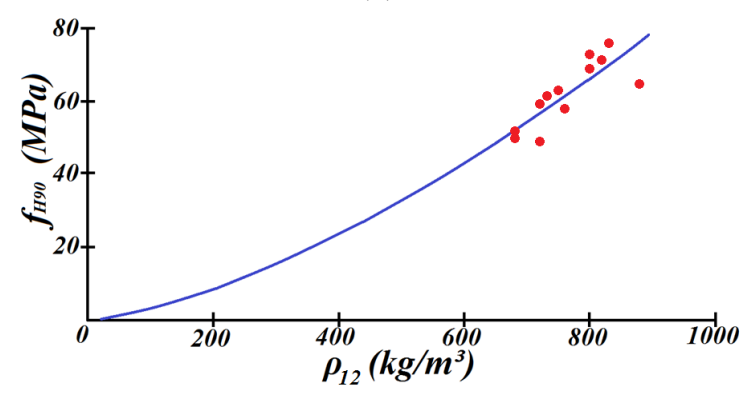

(c)

Figure 1. Regression models: relation between density and strength in compression parallel to the grain (a); density and hardness parallel to the grain (b); density and hardness normal to the grain (c)
P-values obtained for $\mathrm{f}_{\mathrm{c} 0}, \mathrm{f}_{\mathrm{s} 0}, \mathrm{E}_{\mathrm{c} 0}, \mathrm{E}_{\mathrm{m}}, \mathrm{f}_{\mathrm{H} 0}$ and $\mathrm{f}_{\mathrm{H} 90}$ were lower than 0.05 . This implies that the obtained settings for these properties are significant. The determination coefficients $\left(R^{2}\right)$ vary from 34 to $69 \%$. Estimative of $f_{\mathrm{H} 0}, f_{\mathrm{H} 90}$ e $f_{c 0}$ in function of density reached $R^{2}$ upper than $60 \%$, what implies a satisfactory quality of the proposed adjustments [17].

The geometric model provided the higher values of $\mathrm{R}^{2}$, emphasizing that to fourteen of the mechanical properties estimated by density, only 6 provided significant adjustments, and of these six properties, only three showed coefficient $\mathrm{R}^{2}$ higher to $60 \%\left(\mathrm{f}_{\mathrm{H} 0}, \mathrm{f}_{\mathrm{H} 90}\right.$ and $\left.\mathrm{f}_{\mathrm{c} 0}\right)$.

Figure 1 presents the better settings of tested models (Table 4).

\section{Conclusions}

The results obtained of this research allow concluding that:

- Based on the variation coefficient, Vatairea sp. characterization can be considered according to the required by Brazilian standard;

- Following the premises of Brazilian Code, Vatairea sp. is categorized as $\mathrm{C} 40$ (dicotyledonous), by presenting a characteristic value of strength in compression parallel to the grain $\left(\mathrm{f}_{\mathrm{c} 0, \mathrm{k}}\right) 51 \mathrm{MPa}$, indicating a potential good performance for light and heavy structures;

- The regression models presented significant estimates and good quality in adjusting ( $\mathrm{R}^{2}$ bigger than $60 \%$ ) only for three among the fourteen mechanical properties investigated: strength in compression parallel to the grain, hardness parallel to the grain and hardness normal to the grain;

- The regression models geometric presented the better settings, followed by logarithmic models.

\section{ACKNOWLEDGMENTS}

By all support provided, the authors are grateful to Higher Education Improvement Coordination (CAPES); National Council for Scientific and Technological Development $(\mathrm{CNPq})$; and to the four Universities involved.

\section{REFERENCES}

[1] Almeida, D. H.; Chahud, E.; Almeida, T. H.; Christoforo, A. L.; Branco, L. A. M. N.; Lahr, F. A. R. Determination of Density, Shear and Compression Parallel to the Grain Strengths of Pariri (Pouteria sp.), Brazilian Native Wood Specie, International Journal of Materials Engineering 2015, 5(5): 109-112.

[2] Souza, M. H.; Incentivo ao uso de novas madeiras para a fabricação de móveis, IBAMA, Brasília, 70p, 1997. 
[3] Christoforo, A. L.; Blecha, K. A.; Carvalho, A. L. C.; Rezende, L. F. S.; Lahr, F. A. R. Characterization of Tropical Woods Species for Use in Civil Constructions, Journal of Civil Engineering Research 2013, 3(3): 98-103.

[4] Lahr, F. A. R.; Propriedades físicas de resistência e de elasticidade de espécies de madeira para emprego em estruturas, Encontro Brasileiro de Madeiras e em Estruturas de Madeiras, v. 3, São Carlos, SP, Brasil, 1989.

[5] Almeida, D. H.; Scaliante, R. M.; Macedo, L. B.; Macêdo, A. N.; Dias, A. A.; Christoforo, A. L.; Junior, C. A. Caracterização completa da madeira da espécie amazônica Paricá (Schizolobium amazonicum HERB) em peças de dimensões estruturais, Revista Árvore, Viçosa-MG, v.37, n.6, p.1175-1181, 2013.

[6] Instituto de Pesquisas Tecnológicas. Fichas de características das madeiras brasileiras. São Paulo. 1998. 420p.

[7] Santos, E. Nossas madeiras. Belo Horizonte. Itatiaia. v.7. 1987.

[8] Associação Brasileira de Normas Técnicas - ABNT. NBR7190. Projeto de estruturas de madeira. Rio de Janeiro, 107 p., 1997.

[9] Almeida, D. H.; Scaliante, R. M.; Christoforo, A. L.; Varanda, L. D.; Lahr, F. A. R.; Dias, A. A.; Junior, C. C. Tenacidade da madeira como função da densidade aparente, Revista Árvore, Viçosa-MG, v.38, n.1, p.203-207, 2014.

[10] Silveira, L. H. C.; Rezende, A. V.; Vale, A. T. Teor de umidade e densidade básica da madeira de nove espécies comerciais amazônicas, Acta Amazonica, Vol. 43(2) 2013: 179-184.
[11] Logsdon, N. B.; Finger, Z.; Estevão, J. G. Descrição Dendrológica e caracterização físico-mecânica da madeira de Amescla-aroeira, Protium heptaphyllum (Aubl.) March. (Burseraceae), Revista Madeira Arquitetura e Engenharia, ano 6, Set-Dez. 2005.

[12] Braz, R. L.; Oliveira, J. T. S.; Rodrigues, B. P.; Arantes, M. D. C. Propriedades físicas e mecânicas da madeira de Toona ciliata em diferentes idades, FLORESTA, Curitiba, PR, v.43, n.4, p.663-670, out/dez, 2013.

[13] Müller, B. V.; Rocha, M. P.; Cunha, A. B.; Klitzke, R. J.; Nicoletti, M. F. Avaliação das Principais Propriedades Físicas e Mecânicas da Madeira de Eucalyptus benthamii Maiden et Cambage, Floresta e Ambiente 2014 out./dez.; 21(4): 535-542.

[14] Melo, J. E.; Coradin, V. T. R.; Mendes, J. C. Classes de densidade de madeira para a Amazônia brasileira. In: Anais do Congresso Florestal brasileiro 6:695-699. São Paulo, SP, Brasil, 1990.

[15] Freitas, T. P.; Feuchard, L. D.; Oliveira, J. T. S.; Paes, J. B.; Arantes, M. D. C. Caracterizações anatômicas e físico-mecânica da madeira de Liquidambar sp., Floresta, Curitiba, PR, v.45, n.4, p.723-734, out/dez, 2015.

[16] Motta, J. P.; Oliveira, J. T. S.; Braz, R. L.; Duarte, A. P. C., Alves, R. C. Caracterização da madeira de quatro espécies florestais, Ciência Rural, Santa Maria, V.44, n.12, p.2186-2192, dez, 2014.

[17] Montgomery, D. C. Design and analysis if experiments. Arizona: John Wiley \& Sons, 2005, 730p. 